\title{
Pengaruh Citra Perusahaan dalam Mempertahankan Eksistensi UMKM Pekalongan di Masa Pandemi Covid-19 dan Era New Normal
}

\author{
Wenti Ayu Sunarjo $^{\left.1^{*}\right)}$, Amalia Ilmiani ${ }^{2)}$, Siti Nurhayati ${ }^{3)}$ \\ ${ }^{1 * 3)}$ Program Studi Manajemen, Fakultas Ekonomi dan Bisnis, Universitas Pekalongan, \\ Indonesia. Jalan Sriwijaya No. 3 Pekalongan, Jawa Tengah, 51115 \\ ${ }^{2)}$ Program Studi Akuntansi, Fakultas Ekonomi dan Bisnis, Universitas Pekalongan, Indonesia \\ Jalan Sriwijaya No. 3 Pekalongan, Jawa Tengah, 51115 \\ E-mail:wentiayu@ unikal.ac.id ${ }^{1 *}$
}

\begin{abstract}
ABSTRAK
Dampak yang dirasakan di masa persebaran virus corona sangat besar, khususnya pada perekonomian negara, salah satu sektor paling rentan adalah UMKM yang merupakan penggerak ekonomi negara. Konsumen mulai membatasi konsumsinya karena kondisi keuangan yang menurun. Terlebih konsumen sangat menginginkan kepuasan saat memilih UMKM yang dirasa mampu memberikan harga yang sesuai dengan kondisi keuangan di masa pandemic covid-19, mampu memberikan pelayanan yang baik, dan mampu mempertahankan eksistensi perusahaan dengan menciptakan image positif, sehingga konsumen merasa puas. Tujuan dari penelitian ini adalah untuk menguji hubungan antara harga dan kualitas pelayanan terhadap kepuasan konsumen melalui citra perusahaan sebagai variabel mediasi. Fokus penelitian untuk menguji dampak wabah covid-19 terhadap bisnis UMKM, bagaimana masyarakat masih konsisten menggunakan produk UMKM Indonesia karena sudah memahami citra dan kualitasnya, sehingga UMKM tetap dapat mempertahankan eksistensinya menghadapi krisis di era tersebut. Tingkat kesiapan teknologi pada penelitian ini berada pada tahap riset dasar dengan target luarannya adalah mendapatkan data hasil melalui kuesioner tentang seberasa besar eksistensi UMKM lokal Indonesia mampu bertahan di masa pandemic covid-19 hingga era new normal. Teknik random sampling digunakan pada penelitian ini untuk memilih responden dengan cara yaitu konsumen produk UMKM lokal Indonesia yang berada di seluruh Indonesia, dengan teknik analisis data menggunakan Structural Equation Modelling (SEM). Hasilnya bahwa citra perusahaan mampu memediasi kualitas pelayanan terhadap kepuasan konsumen, namun tidak terbukti memediasi harga terhadap kepuasan pelanggan. Hal ini membuka celah bagi penelitian yang akan datang.
\end{abstract}

Kata kunci: Citra Perusahaan; Covid-19; Era New Normal; Kepuasan Konsumen; UMKM.

\begin{abstract}
The impact felt during the spread of the corona virus was very large, especially on the country's economy, one of the most vulnerable sectors is MSMEs which are the driving force of the country's economy. Consumers began to limit their consumption due to deteriorating financial conditions. Moreover, consumers really want satisfaction when choosing MSMEs that are considered able to provide prices that are in accordance with financial conditions, are able to provide good service, and are able to maintain the company's existence by creating a positive image, so that consumers feel satisfied. The purpose of this study was to examine the relationship between price and service quality customer satisfaction through corporate image as a mediating variable. The focus of the research is to examine the impact of the COVID-19 outbreak on MSME businesses, how people continue to consistently use Indonesian MSME products because they already understand
\end{abstract}


their image and quality, so that MSMEs can still maintain their existence in facing the crisis in that era. The level of technological readiness in research. This is at the basic research stage with the output target is to obtain data from a questionnaire about how great the existence of Indonesian local MSMEs is able to survive during the COVID-19 pandemic until a new era normal. The random sampling technique used, with data analysis techniques using Structural Equation Modeling. The result is that company image is able to mediate service quality on customer satisfaction, but is not proven to mediate customer satisfaction prices.

Keyword: Company Image; Consumer Satisfaction; Covid-19; New Normal Era; MSMEs.

\section{PENDAHULUAN}

Isu hangat dunia internasional dari dampak pandemi covid-19 telah dialami oleh hampir semua negara, termasuk salah satunya juga Indonesia. Era pandemi covid-19 yang telah merusak rantai pasokan dirasakan secara global, dan berdampak pada menurunnya harga komoditas, hingga mengakibatkan pula pada penurunan ekonomi. Salah satu sektor yang dinilai paling rentan di masa pandemi covid-19 adalah Usaha Mikro Kecil dan Menengah (UMKM). Tampak bahwa eksistensi UMKM pada masa pandemi mulai terasa terguncang, bahkan tidak sedikit yang mengalami penurunan (Abu et al., 2021).

Saat ini UMKM berupaya menyelamatkan diri dengan upaya untuk berlomba-lomba menstabilkan kondisi dengan berbagai cara. Salah satu cara yang dilakukan adalah dengan tetap fokus pada pemenuhan akan kebutuhan konsumen di masa pandemi covid-19. Selanjutnya semakin banyak UMKM yang berupaya untuk melebarkan sayap dengan mencoba melakukan berbagai hal, diantaranya berkreasi dan berinovasi pada produk maupun pemasarannya guna mempertahankan eksistensi usahanya agar tidak mengalami kebangkrutan (Kusumastuti, 2020). Hal tersebut membuat persaingan diantara perusahaan semakin terbuka lebar dan semakin ketat di masa ini (Rosmadi, 2021), terkait faktor kesuksesan perusahaan sangat ditentukan oleh tingkatan kepuasan konsumen. Perusahaan berlomba-lomba menciptakan kepuasan konsumen, dan kepuasan konsumen tersebut hanya dapat tercapai dengan cara secara terus-menerus memberikan pelayanan yang berkualitas kepada konsumennya (Fikri Sirhan, Wiyani Wahyu, 2016). Pelayanan yang baik sering dinilai oleh konsumen secara langsung dari pelayanan seorang karyawan, maka diperlukan strategi dan usaha untuk dapat meningkatkan kualitas sistem pelayanan yang diberikan agar mampu memenuhi serta meningkatkan keinginan dan kepuasan konsumen.

Salah satu faktor penentu pada kepuasan konsumen, khususnya di masa pandemi covid19 dan era new normal adalah adanya kualitas pelayanan, dimana perusahaan harus berupaya 
menekan harga, dan meningkatkan kualitas pelayanan jasa yang dirasa mampu memberikan banyak kemudahan dan keuntungan untuk menciptakan kepuasan pelanggan atau konsumen (Kamila, 2021; Safitri \& Dewa, 2020). Perusahaan akan mengharapkan pendapatan yang semakin meningkat, serta dalam jangka panjang perusahaan dapat terus berkembang sejalan dengan meningkatnya kepercayaan konsumen melalui peningkatan kegiatan pelayanan yang berdampak pada tercapainya kepuasan konsumen (customer satisfaction) (Panjaitan \& Yuliati, 2016; Lubis \& Andayani, 2018).

Citra perusahaan mampu memberikan peranan yang penting dalam mempertahankan kondisi perusahaan, khususnya dimasa pandemi covid-19 dan di era new normal (Erlangga \& Masitoh, 2020), dimana UMKM perlu melakukan pembentukan citra perusahaan dalam menjaga kepuasan konsumen (Manalu et al. 2020). Citra perusahan bukan hanya dapat berdampak pada persepsi konsumen pada penilaian tentang baik atau buruknya suatu perusahaan, namun dapat berdampak pula pada permasalahan internal perusahaan.

Harga yang merupakan hal utama dan akan menjadi pertimbangan pelanggan dalam membeli atau tidak suatu produk atau jasa yang ditawarkan oleh perusahaan. Salah satu hal yang menjadi penilaian pelanggan yaitu ketika harga yang diberikan perusahaan sebanding dengan produk atau jasa yang ditawarkan, maka hal ini akan berpengaruh pada citra perusahaan (Dewi, 2014), dan dengan pertimbangan pemberian harga yang pantas atau disesuaikan dengan kualitas produk atau jasa, maka akan berpengaruh pula terhadap kepuasan pelanggan (Maulana, 2016).

Bermula dari pemikiran seorang peneliti tentang dasar dari skala kualitas pelayanan adalah sebuah model gap yang dikemukakan oleh (Parasuraman et al. 1985). Selanjutnya Cronin Jr \& Taylor (1992) menciptakan SERVPERF, yaitu ukuran berbasis bantuan dengan menampilkan kekurangan dari model SERVQUAL yang dibuat oleh (Parasuraman et al. 1988; Parasuraman et al. 1994), dimana terdiri dari lima pengukuran yang lengkap yaitu: tangibilitas, keandalan, jaminan, daya tanggap dan empati. Lima pengukuran tersebut umumnya digunakan dalam kualitas administrasi pada penilaian di berbagai daerah eksplorasi. Lima dimensi tersebut secara komprehensif sangat diperlukan dalam peningkatan kualitas perusahaan, khususnya kualitas pelayanan yang berdampak pada kepercayaan konsumen dan dapat berpengaruh pada loyalitas konsumen dan dampaknya pada kepuasan konsumen (Chien \& Chi, 2019).

Sejalan dengan penelitian Maulana (2016) yang menganalisis kekuatan dan arah pada pengaruh variabel kualitas layanan dan harga terhadap kepuasan pelanggan dengan ditunjukkan hasil bahwa variabel kualitas layanan dan harga berpengaruh terhadap kepuasan 
pelanggan. Selain Itu tampak pada hasil penelitian yang dilakukan (Chien \& Chi, 2019; Yamin, 2013; Safitri, et al. 2016) bahwa citra perusahaan memiliki efek peningkatan yang signifikan terhadap kepuasan pelanggan. Dalam bisnis, citra perusahaan adalah penerima yang dipersepsikan akan mempertimbangkan produk dari segi harga dan kualitas, begitupula layanan yang diberikan oleh perusahaan tersebut apakah tinggi, sedang, atau bahkan kurang, sehingga memudahkan untuk mengukur kepuasan pelanggan dan juga loyalitas pelanggan.

Zeithaml et al. (1996) mengemukakan bahwa kualitas administrasi pada perilaku pelanggan dapat diatur sebagai harapan sosial yang pasti dan negatif. Pada intinya ketika penilaian pelanggan terhadap item atau administrasi organisasi mencapai tingkat tertentu, menandakan adanya peningkatan kepuasan pelanggan (Chien \& Chi, 2019).

Kajian literatur dan fenomena yang terjadi menjadi dasar penelitian ini untuk menganalisis pengaruh dari citra perusahaan bagi kepuasan konsumen perlu diteliti secara mendalam, khususnya pada konteks UMKM dan di masa pendemi covid-19 dan era new normal, karena di masa tersebut banyak permasalahan ekonomi yang dirasakan perusahaan. Penelitian ini bertujuan untuk menguji hubungan antara harga dan kualitas pelayanan terhadap kepuasan konsumen melalui citra perusahaan sebagai variabel mediasi. Dapat dijelaskan bahwa fokus penelitian ini adalah mengkaji dampak wabah Covid-19 terhadap bisnis UMKM, bagaimana masyarakat masih konsisten untuk menggunakan produk UMKM Indonesia karena kualitas layanannya yang berdampak pada adanya citra baik perusahaan, serta perhatian terhadap tingkat kesesuaian harga dengan daya beli konsumen Pekalongan, sehingga UMKM tetap dapat mempertahankan eksistensinya menghadapi krisis ekonomi pada era tersebut. Berdasar uraian tersebut, selanjutnya dirumuskan hipotesis sebagai berikut:

H1 : Harga berpengaruh positif dan signifikan terhadap citra perusahaan.

H2 : Kualitas Pelayanan berpengaruh positif dan signifikan terhadap citra perusahaan.

H3 : Harga berpengaruh positif dan signifikan terhadap kepuasan konsumen melalui citra perusahaan.

H4 : Kualitas pelayanan berpengaruh positif dan signifikan terhadap kepuasan konsumen melalui citra perusahaan.

H5 : Citra perusahaan berpengaruh positif dan signifikan terhadap kepuasan konsumen.

\section{METODE PENELITIAN}

Jenis penelitian ini adalah asosiatif kausal dengan menggunakan pendekatan penelitian kuantitatif, dengan cara pencarian terhadap pola hubungan dan/atau pola pengaruh diantara 
variabel-variabel yang terdapat pada satu objek yang diteliti, bertujuan mengetahui bagaimana pengaruhnya masing-masing varibel (variabel dependen atau variabel terikat dan variabel independen atau variabel bebas, serta variabel mediasi). Metode kuantitatif ini digunakan untuk menguji antar satu variabel dengan variabel lainnya dan menggunakan dengan data primer yang dilakukan pada penelitian ini untuk mendapatkan suatu akurasi data dari jawaban responden, dimana pengumpulan data dilakukan dengan metode survei yang bertujuan untuk mengumpulkan informasi dari responden dengan menggunakan daftar pertanyaan atau kuesioner yang disampaikan pada responden penelitian secara langsung (Sugiyono, 2012).

Populasi dalam penelitian ini adalah seluruh konsumen atau masyarakat yang menggunakan atau mengkonsumsi produk UMKM yang tersebar di kota Pekalongan, Jawa Tengah. Jumlah populasi yang tidak dapat dihitung dengan pasti, yaitu seluruh konsemuen produk UMKM yang tersebar di kota Pekalongan, Jawa Tengah. Peneliti hanya memberikan kriteria yaitu konsumen yang tetap konsisten untuk membeli atau mengkonsumsi produk lokal UMKM kota Pekalongan di masa pandemi covid-19 dan di era new normal.

Analisis yang dilakukan pada penelitian ini yaitu dilakukan dnegan cara penarikan hasil melalui pengisian angket atau kuesioner dari sampel penelitian atau responden. Selanjutnya teknik pengambilan sampel dilakukan dengan teknik random sampling. Metode ini digunakan untuk memilih secara acak responden yang ditemui dan dipilih dengan ketentuan bagi respondem yang bersedia berpartisipasi dalam mengisi daftar pertanyaan atau kuesioner guna memberikan informasi terkait penelitian ini.

Daftar pertanyaan atau kuesioner yang diberikan pada responden atau sampel penelitian diditribusikan melalui formulir secara online, melalui media sosial yaitu whatsapp, baik whatsapp personal maupun dibagikan melalui grup-grup whatsapp yang ada. Pertimbangan utama. mengingat penelitian ini dilakukan pada masa pandemi covid-19, sehingga dirasa tepat untuk mendukung pencegahan penularan virus corona, maka tidak dilakukan distribusi secara langsung pada responden sehingga mengurangi intensitas pertemuan dengan masyarakat atau responden secara langsung. Dalam penelitian ini juga dilakukan untuk menguji hipotesis melalui teknik analisis menggunakan Structural Equation Modelling (SEM) dengan desain penelitian yang diintegrasikan menggunakan angket kuesioner dari variabel-variabel yang telah diujikan. Variabel tersebut, diantaranya: harga, kualitas pelayanan, citra perusahaan, kepuasan konsumen.

Selanjutnya dalam menggambarkan hubungan antar variabel-variabel penelitian, maka 
disajikan gambar model penelitian, diamana tampak pada gambar tentang model penelitian dengan menyajikan gambar hubungan antar masing-masing variabel yang diusulkan. Sebanyak 5 hipotesis penelitian diusulkan, seperti pada gambar 1 model penelitian berikut.

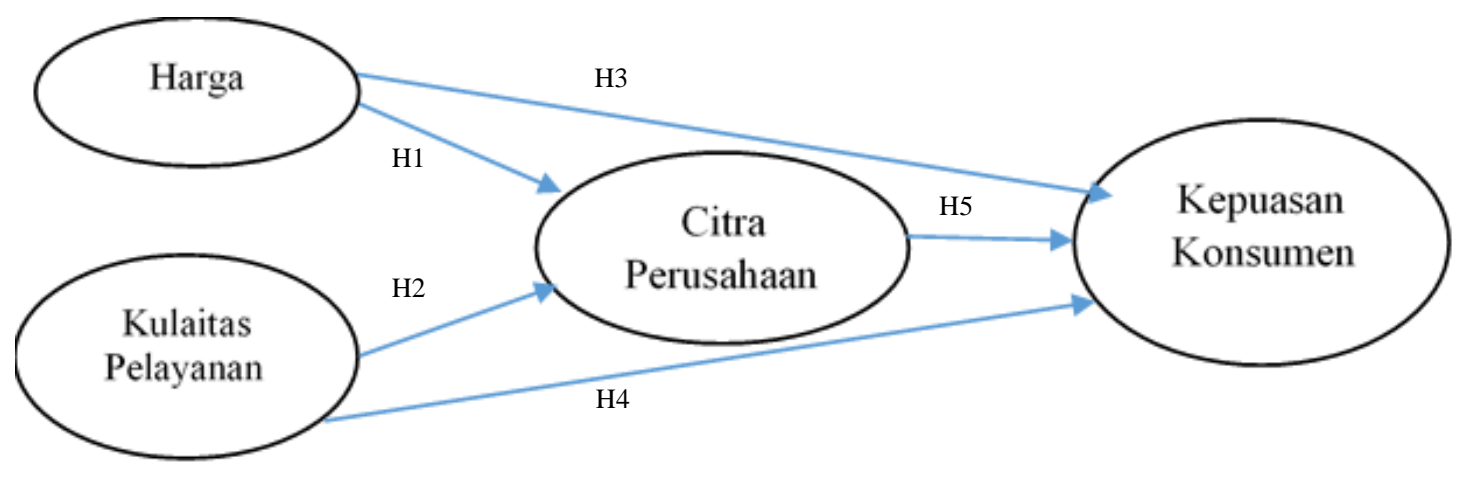

Gambar 1. Model Penelitian

Tabel 1. Definisi Operasional Variabel

\begin{tabular}{|c|c|c|}
\hline Variabel & Indikator & Sumber \\
\hline Harga & $\begin{array}{l}\text { 1. Harga produk sesuai dengan kualitas produk } \\
\text { 2. Harga produk sesuai dengan manfaat produk } \\
\text { 3. Harga produk dapat dijangkau oleh semua konsumen } \\
\text { 4. Harga produk bervariasi } \\
\text { 5. Harga produk dapat bersaing dengan produk lain }\end{array}$ & $\begin{array}{l}\text { Kotler } \\
\text { Armstrong } \\
(2008)\end{array}$ \\
\hline $\begin{array}{l}\text { Kualitas } \\
\text { Pelayanan }\end{array}$ & $\begin{array}{l}\text { a. Tangible } \\
\text { 1. Terjaga kualitas kebersihan } \\
\text { 2. Mendahulukan konsumen sesuai antrean } \\
\text { b. Empati } \\
\text { 1. Perhatian pada tiap konsumen } \\
\text { c. Reliability } \\
\text { 1. Konsisten dalam memberikan pelayanan } \\
\text { 2. Memberikan penanganan administrasi yang baik } \\
\text { b. Responsiveness } \\
\text { 1. Pelayanan secara cepat } \\
\text { 2. Memiliki kompetensi pengetahuan sesuai dengan } \\
\text { 3. Pelayanan yang ramah kepada semua konsumen }\end{array}$ & $\begin{array}{l}\text { Evans \& } \\
\text { Lindsay (2000) }\end{array}$ \\
\hline $\begin{array}{l}\text { Citra } \\
\text { Perusahaan }\end{array}$ & $\begin{array}{l}\text { 1. Reputation } \\
\text { 2. Image } \\
\text { 3. Public Relation }\end{array}$ & $\begin{array}{l}\text { Brunner et al., } \\
(2008)\end{array}$ \\
\hline $\begin{array}{l}\text { Kepuasan } \\
\text { Konsumen }\end{array}$ & $\begin{array}{l}\text { 1. Overall satisfaction } \\
\text { 2. Expectation } \\
\text { 3. Experience }\end{array}$ & $\begin{array}{l}\text { Nam, et al., } \\
(2011)\end{array}$ \\
\hline
\end{tabular}

Sumber: data diolah, 2021

\section{HASIL DAN PEMBAHASAN}


Penelitian ini mengumpulkan sampel sebanyak 206 responden. Total sebanyak 250 kuesioner telah disebarkan, dan yang terkumpul sebanyak 215 kuesioner, namun setelah di lakukan pengecekan pada hasil jawaban, ternyata 9 kuesioner yang kembali tidak lengkap pengisiannya, maka terpaksa tidak kita pakai pada tahapan pengolahan data sebagai sampel. Kuesioner yang disusun pada penelitian ini sebanyak 15 pertanyaan yang harus diselesaikan oleh responden. Semua item menggunakan skala likert kemudian diukur pada likert lima poin skala dengan 1 menunjukkan "sangat tidak setuju" sampai 5 menunjukkan "sangat setuju".

Sampel penelitian ini merupakan konsumen yang pernah belanja pada UMKM di wilayah kota Pekalongan. Sampel diambil secara acak dengan menyebarkan kuesioner melalui pra pertanyaan, jika yang mendapatkan kuesioner merupakan konsumen UMKM Pekalongan, maka akan berlanjut pada mengisi pertanyaan yang telah tersaji, namun jika bukan merupakan konsumen UMKM Pekalongan, maka tidak perlu melanjutkan pengisian kuesioner tersebut.

Sebanyak 206 responden dengan beberapa karakteristik, dan untuk gender yang terbanyak adalah perempuan dengan jumlah sebanyak 168 responden (81,5\%), sedangkan konsumen yang menjadi responden dengan jenis kelamin laki-laki sebanyak 32 responden $(8,5 \%)$. Jika berdasarkan riwayat pendidikan, maka yang menduduki jumlah terbanyak adalah yang berpendidikan SMA, sebanyak 88 responden $(42,8 \%)$ dan yang paling sedikit adalah responden dengan pendidikan S2 sebanyak 2 responden $(0,9 \%)$. Sisanya responden memiliki pendidikan S-1, diploma, SLTP, SD. Rentang usia responden 17 s.d. 53 tahun keatas. Responden terbanyak berusia 44-52 sebanyak 85 responden (41,3\%), sedangkan usia responden 17 s.d. 25 merupakan jumlah terendah yaitu sebanyak 13 responden (6,3\%). Artinya masyarakat usia dewasa lebih cenderung menjadi konsumen UMKM Pekalongan dibanding usia remaja atau usia tua. Secara tidak langsung dapat diartikan bahwa konsumen UMKM Pekalongan kecenderungan adalah orang dewasa berusia 44 hingga 52 tahun.

Tabel 2. Karakteristik Respondents

\begin{tabular}{llll}
\hline Demografi & Kategori & Jumlah & Persentase \\
\hline Gender & Perempuan & 168 & 81,5 \\
Total & Laki-laki & 32 & 8,5 \\
Riwayat Pendidikan & & $\mathbf{2 0 6}$ & $\mathbf{1 0 0 . 0}$ \\
& S-2 & 2 & 0,9 \\
& S-1 & 74 & 36 \\
& D-3 & 27 & 13,1 \\
& SMA & 88 & 42,8
\end{tabular}




\begin{tabular}{llll} 
& SLTP & 12 & 5,8 \\
Total & SD & 3 & 1,4 \\
Usia & & $\mathbf{2 0 6}$ & $\mathbf{1 0 0 . 0}$ \\
& 17-25 years & 13 & 6,3 \\
& 26-34 years & 37 & 18 \\
& 35-43 years & 42 & 20,4 \\
& 44-52 years & 85 & 41,3 \\
Total & $>53$ years & 29 & 14 \\
\hline
\end{tabular}

Sumber: data diolah, 2021

Tabel 3. Goodness of Fit untuk Mengukur Model Struktural SEM

\begin{tabular}{lclc}
\hline \multicolumn{1}{c}{ Fit Indices } & $\begin{array}{c}\text { Recommended } \\
\text { value }\end{array}$ & Suggest by author & $\begin{array}{c}\text { Measurement } \\
\text { model }\end{array}$ \\
\hline $\begin{array}{l}\boldsymbol{\chi} \mathbf{2} /(\mathbf{d f}) \\
\begin{array}{l}\text { Goodness of fit index } \\
\text { (GFI) }\end{array}\end{array}$ & $\leqslant 3$ & Hayduck (1987) & 0,961 \\
$\begin{array}{l}\text { Adjusted for degrees of } \\
\text { freedom (AGFI) }\end{array}$ & $\geqslant 0.8$ & Scott (1994) & 0,962 \\
$\begin{array}{l}\text { Normed fit index (NFI) } \\
\begin{array}{l}\text { Comparative fit index } \\
\text { (CFI) }\end{array}\end{array}$ & $\geqslant 0.8$ & Scott (1994) & 0,933 \\
$\begin{array}{l}\text { Root mean square error } \\
\text { of } \\
\text { approximation (RMSEA) }\end{array}$ & $\leqslant 0.08$ & $\begin{array}{l}\text { Hair et al. (1998) } \\
\text { Bagozzi and Yi }\end{array}$ & $\begin{array}{l}\text { Bagozzi and Yi } \\
(1988)\end{array}$ \\
\hline
\end{tabular}

Sumber: data diolah, 2021

Tabel 4. Uji Hipotesis

\begin{tabular}{lcc}
\hline \multicolumn{1}{c}{ Hypotheses } & P & Support \\
\hline H1 : Harga $\rightarrow$ Citra perusahaan & 0,218 & Ditolak \\
H2 : Kualitas Pelayanan $\rightarrow$ Kepuasan & 0,000 & Diterima \\
Konsumen & & \\
H3 : Harga $\rightarrow$ Citra Perusahaan $\rightarrow$ & 0,272 & Ditolak \\
Kepuasan Konsumen & & Diterima \\
H4 : Kualitas Pelayanan $\rightarrow$ Citra & 0,000 & Diterima \\
$\begin{array}{l}\text { Perusahaan } \rightarrow \text { Kepuasan Konsumen } \\
\text { H5 : Citra Perusahaan } \rightarrow \text { Kepuasan } \\
\text { Konsumen }\end{array}$ & 0,000 & \\
\hline
\end{tabular}

Sumber: data diolah, 2021

Kuesioner yang telah dianggap valid, selanjutnya dilakukan pengolahan data. Pengolahan data menggunakan analisis SEM AMOS. Hasil analisis pada model penelitian ini telah memenuhi syarat goodness of fit, dengan kriteria nilai sebagai berikut: Chi-square= $61,355, \mathrm{df}=67$, Prob $=0,671$, RMSEA $=0,000$, GFI $=0,962$, AGFI $=0,933, \mathrm{Cmin} / \mathrm{df}$ $=0,961$, TLI $=1,004 / \mathrm{NFI}, \mathrm{CFI}=1,000$. Hasil tersebut dapat dikatakan jika model 
penelitian ini fit dan telah sesuai dengan standar dari pengukuran goodness of fit menurut para ahli yang tersaji pada tabel 3 .

Hasil pengujian hipotesis (tampak pada tabel 4) disimpulkan bahwa dari lima hipotesis yang dirumuskan, dua diantaranya ditolak. Selanjutnya dapat menjadi deskripsi kesimpulan bahwa pada $\mathrm{H} 1$ ditolak yaitu pengaruh harga terhadap citra perusahaan. Harga berpengaruh negatif $(0,218)$ terhadap citra perusahaan. Hasil ini sejalan dengan penelitian Sigit (2016), dimana harga tidak memengaruhi citra dari suatu perusahaan, artinya berapapun harga yang ditawarkan atau diberikan pada konsumen tidak memengaruhi citra atau image dari sebuah perusahaan, karena masyarakat sudah percaya dan loyal dengan citra dari suatu perusahaan yaitu UMKM, maka harga tidak menjadi persoalan mutlat untuk mau atau tetap membeli dana atau menggunakan produknya. Hasil penelitian ini tampak berbanding terbalik dengan penelitian (Andriyana, 2018; Afif, 2020) yang mengungkapkan bahwa persepsi harga berpengaruh signifikan terhadap citra perusahaan. Artinya harga yang sesuai menurut konsumen akan berdampak baik pada citra atau image suatu perusahaan.

Selanjutnya pada hasil H2 adalah didukung, yaitu pengaruh kualitas pelayanan terhadap citra perusahaan. Kualitas pelayanan berpengaruh positif dan sig $(0,000)$ terhadap citra perusahaan, artinya hasil ini mendukung penelitian (Chen \& Chen, 2014; Oskan, et al., 2019). Semakin baik pelayanan yang diberikan oleh perusahaan (UMKM), maka semakin baik citra perusahaan. Kecenderungan jika citra perusahaan atau image UMKM baik, maka dapat dikatakan bahwa kualitas dalam melayani konsumen baik pula atau menjadi prioritas utama UMKM.

Hasil penelitian pada H3 hasilnya adalah ditolak, yaitu pada pengaruh Harga terhadap kepuasan konsumen yang dimediasi oleh citra perusahaan. Harga berpengaruh negatif terhadap Kepuasan Konsumen melalui Citra Perusahaan (0,272). Hasil ini telah mendukung penelitian sebelumnya yang dilakukan (Hidayat \& Firdaus, 2014), bahwa harga berpengaruh negatif terhadap kepuasan pelanggan. Meskipun suatu perusahaan mengadakan diskon besarbesaran atau memberikan harga yang lebih ekonomis dibanding kompetitor, namun kenyataanya tidak berpengaruh pada kepuasan konsumen, artinya kepuasan konsumen bukan terletak pada harga produk yang mampu dibawah harga standar pasar. Sedangkan Afif (2020) dan Wang (2020) mengemukakan hal yang sebaliknya, dimana pada penelitiannya tampak bahwa harga berpengaruh positif dan signifikan terhadap kepuasan konsumen melalui citra perusahaan.

Selanjutnya pada H4 tampak hasilnya didukung, yaitu pengaruh kualitas pelayanan terhadap kepuasan konsumen yang dimediasi oleh citra perusahaan. Sejalan dengan 
penelitian (Ramdhani et al., 2011; Sitorus \& Yustisia, 2018) bahwa kualitas pelayanan berpengaruh positif dan sig $(0,000)$ terhadap kepuasan konsumen melalui citra perusahaan. Jika konsumen merasa mendapat pelayanan yang baik, maka citra perusahaan akan meningkat, dan secara otomatis konsumen akan merasakan kepuasan. Maka kualitas pelayanan dari UMKM menjadi hal penting bagi kepuasan konsumen (customer satisfaction).

Hipotesis terakhir yaitu H5 hasilnya didukung, yaitu pengaruh antara citra perusahaan terhadap kepuasan konsumen. Sejalan dengan Hassan et al. (2019) dan Chien \& Chi (2019) bahwa citra perusahaan berpengaruh positif dan sig $(0,000)$ terhadap kepuasan konsumen. Dikatakan bahwa ketika citra perusahaan yaitu citra atau image UMKM baik, maka konsumen merasa puas, konsumen yang merasa puas pada suatu produk UMKM diakibatkan karena adanya citra atau image positif perusahaan atau citra UMKM yang baik di mata masyarakat.

\section{KESIMPULAN DAN SARAN}

Penelitian ini dapat disimpulkan bahwa dalam membangun sebuah citra perusahaan bukan hanya diperlukan pertimbangan dari segi kompetisi harga saja, namun pentingnya dalam sebuah pelayanan yang baik pada semua pelanggan atau konsumen, baik pelanggan tetap atau konsumen baru agar semakin percaya dan yakin untuk terus mengkonsumsi produk atau memakai jasa perusahaan kita, serta mau menginformasikan tentang citra perusahaan dengan citra yang baik pada masyarakat luas. Melalui hal ini akan dapat menjadi ajang promosi terselubung. Maka kiranya penting bagi UMKM mengelola konsumennya agar tidak beralih haluan pada UMKM lain. Citra perusahaan yang telah terbentuk hendaknya tetap dipertahankan, agar konsumen selalu merasa puas dan semakin loyal dalam mengonsumsi produknya, mengajak konsumen untuk terus menggunakan produknya dan setelah merasa puas, maka akan berdampak pada loyalitas dan keberlanjutan.

Hasil penelitian ini dapat menjadi acuan bagi UMKM untuk terus meningkatkan eksistensinya, khususnya di masa pandemi Covid-19 dan era new normal. Dari hasil penelitian ditemukan bahwa harga tidak memengaruhi bagaimana citra perusahaan. Seberapapun harga yang ditawarkan dapat bersaing jika citra perusahaan baik di mata masyarakat, dan sebaliknya. Maka dapat disimpulkan bahwa kecenderungan konsumen lebih mencari UMKM yang memiliki citra perusahaan lebih baik.

Hasil penelitian juga tampak bahwa pada masa pandemi covid-19 hingga era new normal, bukan harga yang menjadi prioritas atau patokan utama bagi konsumen UMKM kota 
Pekalongan untuk mencapai kepuasannya, melainkan lebih pada kualitas pelayanan, dimana UMKM Pekalongan mampu memberikan pelayanan dengan baik pada konsumen secara berkesinambungan, maka akan membentuk citra atau image perusahaan yang baik dan akan berdampak bagi kepuasan konsumen.Selain itu studi ini memberikan kontribusi penting bagi pemerintah untuk melakukan sosialisasi pada UMKM Pekalongan agar tetap mempertahankan citra perusahaan guna peningkatan perekonomian daerah dan peningkatan UMKM Kota Pekalongan.

Penelitian kami tidak terlepas dari keterbatasan, maka dapat menjadi saran bagi peneliti di masa yang akan datang. Pertama, karena penelitian ini dilakukan pada masyarakat yang mengkonsumsi produk UMKM di kota Pekalongan yang tergolong kota kecil di wilayah provinsi Jawa tengah, Indonesia, maka di masa yang akan datang dapat dilakukan penelitian dengan lokus yang berbeda, misal pada kota besar, atau kota lain dengan karakteristik dan budaya masyarakat yang berbeda, mungkin akan didapatkan hasil kebaruan berikutnya. Kedua, penelitian ini dilakukan di masa pandemi covid-19 dan menggunakan kuesioner yang dibagikan secara online, maka tidak dapat terpantau secara langsung untuk meminimalisir pertanyaan yang tidak dapat dijawab secara langsung oleh responden, maka di masa yang akan datang dapat diujikan pada responden secara langsung, dan dapat dilakukan dengan wawancara pada para responden yaitu konsumen UMKM kota Pekalongan sehingga diharapkan akan mendapat informasi yang dapat memperkuat penelitian selanjutnya. Ketiga, penelitian kami menggunakan sampel secara random tanpa dibatasi dengan kriteria pengikat sampel sehingga hasil yang didapatkan bukan spesifik pada sampel dengan kriteria tertentu, maka saran bagi penelitian di masa yang akan datang dapat mengambil sampel dengan kriteria khusus, sehingga hasil penelitian akan lebih terfokus atau didapatkan hasil penelitian yang lebih spesifik. Keempat, penelitian selanjutnya dapat menambahkan variabel lain yang dirasa releven dengan penelitian agar didapatkan pula hasil yang lebih meluas dan mendalam lagi (dapat digeneralisasikan), seperti variabel promosi word of mouth (WOM), loyalitas konsumen, dan lain sebagainya.

\section{REFERENSI}

Abu, I., Sultan, M., \& Putra, E. R. (2021). Basamo Samarinda'S Herbal and Herbal Health Business in the Midst of the Pandemic Covid-19. Berkala Akuntansi dan Keuangan Indonesia, 6(1SP), 34. https://doi.org/10.20473/baki.v6i1sp.26318.

Andriyana, A. (2018). Pengaruh Kualitas Pelayanan dan Persepsi Harga terhadap Citra Perusahaan (Studi Kasus pada PO. Pariwisata Gapuraning Rahayu Ciamis) (Doctoral dissertation, Universitas Siliwangi). 
Balmer, John M.T., Lin, Z., Chen, W., \& He, X. (2020). The Role of Corporate Brand Image for B2B Relationships of Logistics Service Providers in China. Journal of Business Research, 117(April), 850-861. https://doi.org/10.1016/j.jbusres.2020.03.043.

Chen, W. J., \& Chen, M. L. (2014). Factors Affecting the Hotel's Service Quality: Relationship Marketing and Corporate Image. Journal of Hospitality Marketing \& Management, 23(1), 77-96.

Chien, L., \& Chi, S. (2019). Corporate Image as a Mediator Between Service Quality and Customer Satisfaction: Difference Across Categorized. Heliyon, 5.

Dewi, S. N. (2014). Analisis Kualitas Produk dan Harga terhadap Citra Perusahaan dan Kepuasan Konsumen Berdampak pada Loyalitas Perusahaan Sari Jati Kabupaten Sragen. Jurnal Perilaku dan Strategi Bisnis, 2(2).

Erlangga, C. Y. (2020). Strategi Public Relation dalam Meningkatkan Citra Perusahaan di Era New Normal Studi Kasus Suvana Jakarta Golf. Jurnal Public Relations (J-PR), $1(2), 122-127$.

Fikri Sirhan, Wiyani Wahyu, S. A. (2016). Pengaruh Kualitas Pelayanan terhadap Kepuasan dan Loyalitas Mahasiswa. Jurnal Bisnis Dan Manajemen, 3(1), 120-134.

Ferdinand, A. (2014). Stuctural Equation Modelling dalam Penelitian Manajeme: Aplikasi Model-Model Rumit dalam Penelitian Untuk Tesis Magister dan Disertasi Doktor (4 ed.). Semarang: Universitas Diponegoro.

Hidayat, D. R., \& Firdaus, M. R. (2016). Analisis Pengaruh Kualitas Layanan, Harga, Kepercayaan, Citra Perusahaan, dan Kepuasan Pelanggan terhadap Loyalitas Pelanggan:(Studi pada Pelanggan Telkom Speedy di Palangka Raya). JWM (Jurnal Wawasan Manajemen), 2(3), 237-250.

Kamila, E. F. (2021). Peran Industri Halal dalam Mengdongkrak Pertumbuhan Ekonomi Indonesia di Era New Normal. LIKUID: Jurnal Ekonomi Industri Halal, 1(1).

Kusumastuti, A. D. (2020). Pengaruh Pandemi Covid-19 terhadap Eksistensi Bisnis UMKM dalam Mempertahankan Business Continuity Management (BCM). EJournal Administrasi Bisnis, 8(3), 224-232.

Lubis, A. S., \& Andayani, N. R. (2018). Pengaruh Kualitas Pelayanan (Service Quality) terhadap Kepuasan Pelanggan PT. Sucofindo Batam. Journal of Applied Business Administration, 1(2), 232-243. https://doi.org/10.30871/jaba.v1i2.619.

Manalu, V. G., Sunarjo, W. A., \& Sulaiman, E. (2020). The Influence Mechanism of Corporate Image: in Examining of Consumer Satisfaction SMSEs Indonesia. Proceding International Sustainable Competitive Advantage (SCA).

Maulana, A. S. (2016). Pengaruh Kualitas Layanan dan Harga terhadap Kepuasan Pelanggan PT. TOI. Jurnal Ekonomi, 7(2).

Özkan, P., Süer, S., Keser, İ. K., \& Kocakoç, İ. D. (2019). The Effect of Service Quality and Customer Satisfaction on Customer Loyalty: The Mediation of Perceived Value of Services, Corporate Image, and Corporate Reputation. International Journal of Bank Marketing.

Panjaitan, J. E., \& Yuliati, A. L. (2016). Pengaruh Kualitas Pelayanan terhadap Kepuasan Pelanggan pada JNE Cabang Bandung. DeReMa Jurnal Manajemen, 11(2).

Ramdhani, M. A., Ramdhani, A., \& Kurniati, D. M. (2011). The Influence of Service Quality Toward Customer Satisfaction of Islamic Sharia Bank. Australian Journal of Basic and Applied Sciences, 5(9), 1099-1104.

Rosmadi, M. L. N. (2021). Penerapan Strategi Bisnis di Masa Pandemi Covid-19. Jurnal IKRA-ITH Ekonomika, 4(1), 122-127.

Safitri, L. A., \& Dewa, C. B. (2020). Analisa Pengaruh Masa New Normal pada Penjualan Online Melalui E-Commerce Shopee. Jurnal Manajemen Dayasaing, 22(2), 117-125.

Safitri, E., Rahayu, M. Indrawati, N.K. (2016). Pengaruh Kualitas Pelayanan dan Citra 
Perusahaan Terhadap Kepuasan Pelanggan dan Loyalitas Pelanggan Service Center [Studi pada Pelanggan Samsung Service Center di Kota Malang]. Jurnal Ekonomi Bisnis Tahun 21(1).

Sigit, I. I. A. (2016). Analisis Pengaruh Suasana Toko, Persepsi Harga dan Kualitas Produk terhadap Minat Beli dengan Citra Merek Sebagai Variabel Mediasi Studi pada Pelanggan Kedai Conel Surakarta (Doctoral dissertation, UNS (Sebelas Maret University)).

Sitorus, T., \& Yustisia, M. (2018). The Influence of Service Quality and Customer Trust Toward Customer Loyalty: The Role Of Customer Satisfaction. International Journal for Quality Research, 12(3).

Sugiyono. (2012). Metode Penelitian Kualitatif, Kuantitatif, dan R\&D. Bandung: Alfabeta.

Wang, Chih-Chuan. (2020). Corporate Social Responsibility on Customer Behaviour: The Mediating Role of Corporate Image and Customer Satisfaction. Total Quality Management \& Business Excellence, 31:7-8, 742-760. DOI: 10.1080/14783363.2018.1444985

Yamin, Regina. (2013). Persepsi Nilai, Persepsi Kualitas dan Citra terhadap Kepuasan Konsumen pada PT. Astra Internasional Daihatsu Manado. Universitas Samratulangi. Manado. Jurnal Emba, 1(3). 